\title{
The Technological Culture of War
}

\author{
Joelien Pretorius \\ University of the Western Cape
}

Bulletin of Science,

The article proceeds from the argument that war is a social institution and not a historical inevitability of human interaction, that is, war can be "unlearned." This process involves deconstructing/dismantling war as an institution in society. An important step in this process is to understand the philosophical and cultural bases on which technology is employed as "tools" of war. The article focuses on such questions as, Is technology just viewed as instruments in the hand of its human masters in war? Does technology take on an autonomous role in war? How should we assess the impact of context (political, economic, and cultural) of technology when employed in war? By exploring these points, the article hopes to provide input into the discussion on the control of war technologies and ultimately the dismantling of war as an institution in society.

Keywords: philosophy of technology; war technologies; instrumentalism; dystopianism; constructivism; revolution in military affairs

$\mathrm{S}$ ince the early 1990s, the United States has been explicitly developing a new model of warfare, referred to as the revolution in military affairs (RMA), and more recently renamed "transformation." In its current form, the RMA involves the incorporation of ever more "advanced" technologies in military organization and tactics, supposedly enhancing intelligence, surveillance, reconnaissance, precision targeting, force mobility, and logistics to "lift the fog of war." Conceptualizations of this model go beyond existing technology, though, to generate a culture of innovation that would drive technological advances for future applications in war.

This model is the latest in a number of RMAs driven by technology since the formation of the modern state. Although technological models of defense have spread (diffused) around the world, the emphasis on technology in warfare is, according to Keegan (1993, p. 390), a particularly Western phenomenon. He argues that Western culture was receptive to the changes that technology presented, and this is one of the main characteristics that led to a "Western manner of war making," that is, a technology-intensive way of fighting wars. Although non-Western states have adopted technological approaches too, the West has been at the forefront of the development and export of military technological models. Thus, these models reflect a Western fetish of technology and as they spread around the world, so this fetish spreads, too.
In examining the technological culture of war, this article will discuss how Western technological values come to be embodied in military artifacts by employing a constructivist approach to technology. In doing so, it will draw on the work of Professor Andrew Feenberg $(1995,1998,1999$, p. x), who attempts to bear what he calls the "burden of constructivist sociology of technology" (see also Wiebe Bijker, 1995). This approach transcends three other common views often implicit in discourses of military technology, namely, a deterministic, instrumental, and dystopian view. Determinism views technology as autonomous and ever advancing, that is, creating (or predetermining) futures (or possibilities) for humans. Humans do not control this process but adapt their way of life to it for their own good. Instrumentalism characterizes technology as enabling humans, that is, technology implies neutral tools in the hands of its users. Humans are the masters, and artifacts are only defined in terms of their functions. The dystopian view argues that technology twists and distorts humanity by imposing technology itself as an end. The aim is to juxtapose these views with a constructivist alternative that offers greater understanding of the meaning of military technology in its social context.

\section{Determinism}

Determinism is a product of a long-held view in Western society that technology maintains a position 
akin to science. From the "realm of reason," that is, an objective realm separate from society, technology is thought of as an autonomous, progressive force, unfolding as if "following a natural trajectory, with existing artifacts being replaced by better artifacts in a Darwinian-like order of succession" (Farrell \& Terriff, 2002, p. 12; Feenberg, 1999, p. vii). For the purposes of this discussion on military technology, such a view would hold that from the crossbow to F16s, military change is driven by the efficiency of design. It is held back only by the speed at which new discoveries are made and integrated into military systems.

Those criticizing the strategic logic of defense systems in the aftermath of World War II and during the Cold War arms race, for example, the former U.S. president Dwight D. Eisenhower (1961) and the British scholar and military analyst Mary Kaldor (1981), pose strong critiques of determinism in military technology. Their analyses show the fallacy of viewing technological development as an autonomous and disinterested process. They criticize the idea that military modernization is the unfolding of "an evolutionary potential inherent" in technology, which will direct (determine) not only warfare, but society in general, as it unfolds (Hirst, 2001, p. 149). It is this aspect of determinism, the fact that technology is not humanly controlled, that President Eisenhower and Harold Lasswell $(1941,1962)$ in his Garrison State expose. They question the deterministic rationality that seems to steer military technological development and acquisition by arguing that humans should and do indeed have control over technology. Military technology is not an autonomous, progressive force that will necessarily provide improved security as it develops, but it is orchestrated by a military-industrial complex, a concept first proposed by C. Wright Mills' (1956) in The Power Elite.

The concept military-industrial complex is used to describe the three-way relationship among the military, arms industry, and government. It is generally used to suggest one of three situations: some kind of collaboration between military and industrial elites to control government, an expanding bureaucracy that comes to control the arms industry in the name of national security, or corporate elites that control the military and government to serve capitalist interests. These situations lead to military build-ups, or what Kaldor (1981) calls "baroque arsenals," where the increase in technological sophistication (means) is not proportional to the increase in security (ends). Technology should therefore be reined in and then applied only when it contributes to security.

\section{Instrumentalism}

It is, however, in maintaining the distinction between means and ends that analyses such as those by Eisenhower and Lasswell succumb to instrumentalism. They assume that technology is a neutral tool and has no inherent meaning of its own. Instead, it can be employed to whatever ends its masters will. The point is thus to apply the "right" technology to obtain chosen ends. Their solution is to wrestle military technological design away from a secretive, undemocratic military-industrial-political-scientific elite, overcoming the military impulse that leads to excessive and decadent military build-ups (according to Kaldor, 1981). Instrumentalism only asks whether given military technologies offer the best technological framework to enhance security in a specific context of objectively given threats.

Such is the nature of the critiques of current U.S. military technology offered by Michael O'Hanlon (1998, 2000), Stephen Biddle (2003), and Bjorn Møller (2002). They question the extent to which the recent wars fought by the United States vindicated its technologically intensive strategies. O'Hanlon and Møller not only doubt the utility of high-tech equipment used in the Gulf War but argue that the war was unique in too many respects to serve as a model for future military campaigns. For Møller, subsequent attempts at exploiting these technolgies in the Balkans, against Iraq, and in Afghanistan have not been particularly convincing. He continues to argue that the U.S. model would be irrelevant for most of the likely military challenges for the future. Traditional interstate war with a "worthy" (read: similarly organized) opponent where advance military technology may be relevant would be unwise for the United States to engage in, while "uncivil" wars call for peace operations and not offensive force and would in any case be wars that the United States would avoid. The "war on terror" would look to homeland defense, placing emphasis on aspects, such as improvements in airport security, intelligence gathering, and similar defensive measures as opposed to military means. Stephen Biddle (2003) delivers a similar critique of RMA technologies' performance in the Afghan case.

Recently analysts have commented on the irrelevance of advanced military technology amid an insurgency in Iraq (see, e.g., Boot, 2005). Drayton (2004) asserts, for example, "Iraq has shown the hubris of a geostrategy that welds the philosophy of the Leviathan to military and technological power." 
Today's wars provide no clear distinction between internal and external wars, civil and military sectors, legitimate bearers of arms and noncombatants and criminals. They are a confluence of war proper, organized crime, and large-scale violations of human rights. This type of warfare has also been dubbed postmodern war by Duffield (1998) and Ignatieff (2000). The U.S. defense model is not applicable to these "new wars" (Kaldor, 1999).

These arguments do not, however, refer to the essence (and constitutive nature) of military technology. They merely identify the mismatch between means (neutral technology) and objectively determinable ends (dealing with contingencies in wars) in conceptualizations of a military model. Thus, instrumentalism does not bring us any closer to a cultural interpretation that would identify the values embodied in military technology and explain how they become incorporated in these devices. This is part of the "question of technology" and requires an approach that goes beyond the means/ends distinction that underlies instrumental reasoning. The question of technology (also translated as "the question concerning technology") is the title of one of Martin Heidegger's (1953/1977) books in which he explores the "control" that modern technology comes to exercise over humans. The next section addresses a dystopian answer to the question of technology.

\section{Dystopianism}

Dystopian critiques of modernity dating from the 1950s and 1960s provide an approach to technology that explores its "substantive" content, not just its instrumental value. Feenberg (1999) summarizes this view as follows:

Technology is not neutral but embodies specific values. Its spread is therefore not innocent. The tools we use shape our way of life in modern societies where technique has become all pervasive. In this situation, means and ends cannot be separated. How we do things determine who we are. Technological development transforms what it is to be human. (p. 2)

Dystopianism tries to reduce technology to its essence to expose its true relationship to humankind and make it possible to understand all the aspects and problems of this relationship.

The essence of the way in which modernity organizes society, according to Ellul (1964), Heidegger (1953/1977), Weber (1905/1958), and McLuhan
(1964), are efficiency and rational control, and these fundamental values are built into technology. Technology "reduces everything to functions and raw materials. Goal oriented technological practices replace practices which embody human meaning. Efficiency sweeps away all other norms and determines an autonomous process of technological development" (Feenberg, 1999, p. viii). Efforts to attach nontechnical meanings to devices are regarded as interference in the rational realm of technology that has a different logic and set of laws. Technology comes to engulf its human creators and threaten their continued spiritual and material existence, precisely because technical rationality overrides common sense, for example, when economic models are based on the idea of unlimited growth in a finite universe (Ellul, 1992, p. 45).

From a dystopian viewpoint, the values of efficiency and control can be pinpointed in modern models of warfare. In imagining future warfare, those conceptualizing U.S. military strategies, for example, focus on capabilities, not threats. Future threats (the who, where, and why dimensions of threat) are said to be too unpredictable to steer future planning, especially in light of the 10 to 30 years R\&D and acquisition cycle of military equipment (U.S. Department of Defense, 2003, p. 6; U.K. Ministry of Defence, 2005). Instead, the emphasis is on the "how" dimension-all the possible capabilities (technologies) that might be employed to threaten the United States and its allies (U.S. Department of Defense, 2002). This is a crucial distinction that shifts the focus from the human to the technological element of warfare. These strategies try to circumvent uncertainty by anticipating a single future in terms of capabilities. A 21 st-century defense force should have capabilities to allow it to respond to the whole plethora of capabilities ("fullspectrum dominance") that might come to threaten the United States. Who the enemy is, is less important than how and with what he or she might fight.

This is referred to as the capabilities-based approach that replaced the threat-based approach in U.S. military planning. This is a mechanistic approach to military transformation, because it reduces threat to a technical problem that can be solved through technological ingenuity. What is thus at stake here is not response to threat but achieving technological superiority in military affairs, which is for those conceptualizing the U.S. model akin to achieving the military high ground. The essence of contemporary military models and technologies is efficiency and control. 
An inquiry into the way in which today's military technology serves technical (as opposed to human) values in warfare focuses first on the impact that digitization has on military culture, what it means to be a soldier and to wage warfare in the computer age (Vest, 2000). Extreme versions of dystopianism go further to show how the latest military technology spells a future where man and machine, military and civilian realms, and peace and war become inseparable (Demchak, 2000, p. 36). Gray (2002) concludes,

\section{When one looks closely at the actual proposed imple- mentations in the form of weapons systems and doctrines and those cheery war "games" the soldiers like to play, it becomes clear that infowar in actuality will just expand war into that new place, cyberspace, and it will just mag- nify long standing trends in postmodern war to add new layers of command and control to the military and to fur- ther deconstruct the difference between peace and war. It also continues the militarization of outer space, the grow- ing integration of humans into weapon systems (cyborg soldiers) and the manic search for new technologies, the latest craze being nanotechnology. (p. 56)}

This type of inquiry provides a partial answer to the question of which values are embodied by today's military technology, but does not answer it sufficiently. It asserts that those who conceptualize military models take as primary premises values of efficiency and control and that these values come to be embodied by modern weapons systems. It thus transcends the means/ends distinction in that the ends are already tied up in technology when it is conceptualized and convincingly show how the values related to functionality impose themselves where these technologies are applied. But to argue that efficiency and rational control are the sum total of meaning embodied by these technologies privileges the role that dominant technological actors play in technological design and negates the role of ordinary people and their life-world experience of these technologies. These life-world experiences would include those of the soldiers who operate military technologies, the enemy who are targeted by them, the civilians who are killed in their line of fire, the international "human shields" that brace a conflict situation to impose a form of restraint on their deployment, those who feel liberated from political oppression as a result of their use, the diverse, transnational lobby groups that protest against their use, and the scores of people who become aware of their existence and application through the mass media or by word of mouth.

\section{Constructivism}

Feenberg, drawing on Habermas's idea of "technization of the lifeworld," attempts to develop an approach that recognizes these life-world meanings experienced by "subordinate" actors and how they come to be embodied by technology (see, e.g., Krogh, 1998). His is thus a nonessentialist argument, because the values that technology embodies are not just from technical rationality (i.e., functional, efficient), but at any given stage will express a range of meanings gathered from past experience. Those who conceptualize military models see efficiency as the main value, but those who "live" these models see other meanings embodied in military technology. Similarly, those whom an advance military force directs itself against understand what is happening from their own past experience. If the question of technology is only confined to the masters of technology (the conceptualizers of arms), there is a divide between technology and meaning. When focusing on ordinary people as well, this is not a divide but a terrain of contestation where different actors engage with the meaning of technology. "Technologies are not merely efficiency devices or efficiency oriented practices, but include their context as these are embodied in design and social insertion" (Feenberg, 1999, p. xiii). Social insertion refers to the way technology is fitted into a social setup, often to contribute to social receptivity of technology. In modern homes, a fireplace, for example, is aesthetically decorated to contribute to the experience of the device as homely and warming. In terms of the users of RMA technology, an interesting aspect is how soldiers are able to customize their gear.

The marginalization of the role of subordinate actors in the search for the meaning of technology is the source of the "deterministic illusion" or the idea that there is an autonomous rationality (whether perceived as progressive or detrimental) inherent in technology. Bijker (1995, pp. 45, 271) explains that technology is social just as institutions are, in that an array of social groups participates in its development. They come together and negotiate what is most favorable for their interests during the design process. This leads to a process of closure whereby a product is adapted to a "socially recognized demand." Like closing a black box, the meaning of the specific technology is fixed, and the fact that the technology was a product of a social process and that it actually expresses certain worldviews and interests is soon forgotten. The final design seems merely the 
(inevitable) product of technical considerations (see also Feenberg, 1999, p. 11).

A constructivist view might seem similar to instrumentalism in that social actors come to define the ends (the socially recognized demands) and design means to achieve them. It differs, however, in that the choice of technology is not just a choice of means; instead, it includes the whole means-ends system. It is not just the uses of technology that are at stake but all of its effects during all the stages of its development and application. Some effects will not necessarily be related to its uses. They may be part of the contextual requirements to apply technology or they may be side effects, but all come to impact on technical choices (Feenberg, 1999, p. 7). The application of cell phone technology for communication purposes necessitates physical contextual requirement (e.g., the erection of cell phone towers that may be perceived to ruin a natural landscape) and cultural contextual requirements (e.g., changing professional and social expectations of being available to receive or make a call). Add to this the debates around the environmental and health side effects of cell phone towers and a more complete picture of the meaning of cell phones in addition to their use emerges.

A constructivist approach not only acknowledges that means and ends are inseparable but introduces contingency into an inquiry into military technology. The end product is not the one and only viable alternative that existed, and its design was not "locked in" from its inception. There are multiple paths for technological development. Only some are taken, and often they are disrupted or changed by other developments (Hirst, 2001, p. 149). The factors determining which paths are taken and how they will proceed are the result of an array of socially negotiated understandings rather than technical superiority. Design reflects the understanding of designers of their role in society and their interests in relation to groups, such as politicians, consumers, and corporate managers (Drake, 1995, p. 349). It also reflects the significance society attributes to certain circumstances (e.g., mobilized public opinion around global climate change will manifest in greener designs).

It is necessary to return to the question of how military technologies come to embody values that lead to a mechanistic approach to war. The mechanistic approach to war is symptomatic of a denial of the social dimensions of technology. But technology is profoundly social. The privileging of technical rationality (efficiency, functionality) in conceptualization of military models reflects a fetish with technology. Why does this happen? In modern society, technology presents itself to society primarily through its function. All other qualities (e.g., aesthetics, spirituality, ethics) are secondary. Unlike with natural objects, this immediate perception of technology as differentiated into primary functional qualities and secondary social qualities rips technology from its social context. The essence of technology becomes for society its function. As such, Feenberg (1999) explains that technology is not viewed as possessing any normative content but rather consists of structures that correspond to its function. "Insofar as structures have an internal causal logic, they can be abstracted from their social surround as an instance of causal principles. All systematic knowledge of technology rests on this type of abstraction" (p. 212). As technical disciplines arise and expand to explain these structures and to pursue their perfection, so they set the criteria for judging technology. Soon, it becomes common sense to see devices only in terms of their structures. Their function (abstracted in this way from their social context) is what links the subjective uses of devices with their internal causal logic. Function thus becomes the link between society and technology, but it remains abstracted from its social context. It is precisely this abstraction that distinguishes technology from, for example, rocks on the beachfront or trees in a forest.

In the same way, this illusion of technology as objective and autonomous is constitutive in the case of military technology, because those who conceptualize it act on the illusion. They do not see a difference in the essence of military technology when employing it in the Gulf War (1990) or the Iraq War (2003), for example. Yet, the former had significantly more international and Iraqi support compared to the latter. The constitutive role of social context on technology is clear. The lack of support for the Iraq War and occupation, and its subsequent manifestation in the insurgency, leads to a failure of one of the main promises of advanced military technology, namely, decisive force. Analysts see this as certain technologies not being applicable to the type of warfare the United States is called upon to fight. Those conceptualizing military technology go back to the drawing board and see how they can fix the (technical) problem and make their technology more suitable for conflict at the insurgency level of conflict. Their fallacy is to see technology as autonomous from its context. Somehow, the wrong technology was applied to the problem. But would the same technologies not have been praised if the Iraq War had been supported more broadly and if the end of formal combat operations meant the acceptance of the United States as liberators? 
A recent Wired magazine article heading reads, "How technology almost lost the war: In Iraq, the critical networks are social-not electronic." The article discusses the inadequacy of advanced technology to "win hearts and minds." The author, Noah Shachtman (2007), quotes John Nagl, who helped to write the U.S. Army's new counterinsurgency manual, as saying

The real problem with network-centric warfare is that it helps us only destroy. But in the 21st century, that's just a sliver of what we're trying to do. It solves a problem I don't have-fighting some conventional enemy - and helps only a little with a problem I do have: how to build a society in the face of technologyenabled, super-empowered individuals.

He then sings the praises of the newly deployed human terrain teams (HTTs) consisting of social scientists, software experts, and people knowledgeable on local culture to serve as "cultural councillors" to each commander.

At face value, the HTTs go beyond the mechanistic approach to warfare. But polarizing the debate into two mutually exclusive extremes where technologycentered approaches in war "destroy" and humancentered approaches "build" society again misses the point. The meaning of technology reveals itself in its social context where it reflects certain social norms but also confirms or undermines other norms. It is "this lifeworld of technology (that) is the place of meaning in modern societies" (Feenberg, 1999, p. 197). Those who conceptualize military models look to the experience of military technologies in the Iraq War to score their efficiency in warfare overall. For constructivists, on the other hand, this experience "constitutes an essential dimension of the contemporary struggle for a humane and livable world" (Feenberg, 1999, p. 199). Sometimes, societies accept that for a future humane and livable world, they may have to contend with technologies that destroy. It is when the destruction does not make sense, for example, when its cause or end goal is suspect (war for oil, cultural discrimination, or geopolitical domination as opposed to a "just war") and its nature is outside acceptable norms of humanitarian law (e.g., proportionality) that military technology is experienced as socially destructive.

\section{Conclusions}

The focus of this article is on the culture that drives contemporary military technological developments and its diffusion worldwide, but it has broader applications that touch on social responsibility at the nexus of science, technology, and world affairs. First, it sheds light on past technological developments in military affairs, such as nuclear weapons. The (ir)rationality of the nuclear arms race and mutual deterrence/assured destruction strategies of the Cold War is embedded in the myth that military technological superiority per se provides security. Development and testing of nuclear weapons systematically ignores the social context of these weapons or deems the context less important than the developments themselves.

Second, the article works from the assumption that war is not inevitable but a social institution that can be dismantled and "uninstituted." Military technology plays a significant role in instituting war, not least through the military-industrial-scientific complex. An important step in dismantling the institution of war is to understand the philosophical and cultural bases on which technology is employed as tools of war.

Last, a constructivist view of military technology dispels the myth that technological "progress" cannot be held back or that the meaning of technology is only related to its function. It recognizes how technology embodies and spreads social values and that the social context in which technology is developed and applied matters. Understanding this is essential when scientist and engineers want to develop socially responsible products of science and technology.

\section{References}

Biddle, S. (2003). Afghanistan and the future of warfare. Foreign Affairs, 82(2), 31-46.

Bijker, W. E. (1995). Of bicycles, bakelites, and bulbs: Towards a theory of sociotechnical change. London: MIT Press.

Boot, M. (2005). The struggle to transform the military. Foreign Affairs, 84(2), 103-118.

Demchak, C. (2000). The RMA in developing states: Dilemmas of image, operation and democracy. National Security Studies Quarterly, 6(4), 1-45.

Drake, W. J. (1995). Conclusion: Policies for the national and global information infrastructures. In W. J. Drake (Ed.), The new information infrastructure: Strategies for US policy (pp. 345-378). New York: Twentieth Century Fund.

Drayton, R. (2005, December 28). Shock, awe and Hobbes have backfired on America's neocons. The Guardian. Retrieved February 6, 2006, from http://www.guardian.co.uk/comment/story/0,3604,1674184,00.html

Duffield, M. (1998). Post-modern conflict: Warlords, post-adjustment states and private protection. Civil Wars, 1(1), 65-102.

Eisenhower, D. (1961). Military-industrial complex speech. Public papers of the presidents, Dwight D. Eisenhower, 1960, pp. 1035-1040. Retrieved November 1, 2005, from http://coursesa.matrix.msu.edu/ hst306/documents/indust.html

Ellul, J. (1964). The technological society (J. Wilkonson, Trans.). New York: Vintage. 
Ellul, J. (1992). Technology and democracy. In L. Winner (Ed.), Democracy in a technological society (pp. 35-50). London: Kluwer Academic.

Farrell, T., \& Terriff, T. (Eds.). (2002). The sources of military change: Culture, politics, technology. London: Lynne Rienner.

Feenberg, A. (1995). Alternative modernity: The technical turn in philosophy and social theory. London: University of California Press.

Feenberg, A. (1998, November). Can technology incorporate values? Marcuse's answer to the question of the age. Paper presented at the conference on The legacy of Herbert Marcuse, University of California, Berkeley. Retrieved February 10, 2006, from http://www-rohan.sdsu.edu/faculty/feenberg/marcuse.htm

Feenberg, A. (1999). Questioning technology. London: Routledge.

Gray, C. H. (2002). Cyborg citizen: Politics in the posthuman age. London: Routledge.

Heidegger, M. (1977). The question concerning technology (W. Lovitt, Trans.). New York: Harper \& Row. (Original work published 1953)

Hirst, P. (2001). War and power in the 21st century: The state, military conflict and the international system. Cambridge, UK: Polity.

Ignatieff, M. (2000). Virtual war. Kosovo and beyond. New York: Henry Holt.

Kaldor, M. (1981). The baroque arsenal. London: Hill \& Wang.

Kaldor, M. (1999). New and old wars: Organised violence in a global era. Cambridge, UK: Polity Press.

Keegan, J. (1993). A history of warfare. New York: Knopf.

Krogh, T. (1998). Technology and rationality. Aldershot, UK: Ashgate.

Lasswell, H. (1941). The garrison state. The American Journal of Sociology, 46, 455-468.

Lasswell, H. (1962). The garrison-state hypothesis today. In S. Huntington (Ed.), Changing patterns of military politics (pp. 51-70). New York: Free Press of Glencoe.

McLuhan, M. (1964). Understanding media: The extension of man. New York: McGraw Hill.

Møller, B. (2002). The revolution in military affairs: Myth or reality? Copenhagen, Denmark: Copenhagen Peace Research Institute.
Retrieved February 6, 2006, from http://www.ihis.aau .dk/ bm/RMA.doc

O'Hanlon, M. E. (1998). Beware the “RMA'nia!” Paper presented to the National Defense University. Retrieved February 6, 2006, from http://www.brookings.edu/views/ohanlon 1998ndu.html

O'Hanlon, M. (2000). Technological change and the future of warfare. Washington, DC: Brookings Institute.

Shachtman, N. (2007). How technology almost lost the war: In Iraq, the critical networks are social-not electronic. Wired, 15.12. Retrieved December 11, 2007, from http://www .wired.com/politics/security/magazine/15-12/ff_futurewar

U.K. Ministry of Defence. (2005). UK defence industrial strategy. Retrieved May 29, 2008, from http://www.official-documents.gov.uk/document/cm66/6697.pdf

U.S. Department of Defense. (2002). National security strategy. Retrieved May 29, 2008, from http://www.comw.org/qdr/fulltext/nss2002.pdf

U.S. Department of Defense. (2003). Military transformation: A strategic approach. Washington, DC: Office of Force Transformation. Retrieved May 29, 2008, from http://www .oft.osd.mil/library/library_files/document_297_MT_Strategy Doc1.pdf

Vest, H.S. (2000). Tomorrow's 'cyberwarriors.' Air and Space Power Chronicles. Retrieved February 24, 2005, from http://www.airpower.maxwell.af.mil/airchronicles/cc/vest.html

Weber, M. (1958). The Protestant ethic and the spirit of capitalism (T. Parsons, Trans.). New York: Scribners. (Original work published 1905)

Wright Mills, C. (1956). The power elite. New York: Oxford University Press.

Joelien Pretorius holds a $\mathrm{PhD}$ degree from the University of Cambridge, U.K. She is currently lecturing in international relations at the University of the Western Cape, Bellville, South Africa. She is a member of Pugwash, an organization concerned with the social application of science and technology in world affairs. 